\title{
Peter Browne on the Metaphysics of Knowledge*
}

\author{
Kenneth L. Pearce \\ Trinity College Dublin
}

December 2, 2019

\begin{abstract}
The central unifying element in the philosophy of Peter Browne (d. 1735 ) is his theory of analogy. Although Browne's theory was originally developed to deal with some problems about religious language, Browne regards analogy as a general purpose cognitive mechanism whereby we substitute an idea we have to stand for an object of which we, strictly speaking, have no idea. According to Browne, all of our ideas are ideas of sense, and ideas of sense are ideas of material things. Hence we can conceive of spiritual things - including even our own spirit - only by analogy. One interesting application Browne makes of his theory is an account of how concepts such as knowledge can be correctly applied to beings that have no intrinsic properties in common, such as non-human animals, humans, angels, and God. I argue that this is best understood as what, in the contemporary literature, is known as a 'multiple realizability' problem and that Browne's solution to this problem has important similarities to functionalist theories in recent philosophy of mind.
\end{abstract}

Peter Browne was a philosopher, theologian, and polemicist belonging to the conservative 'high church' faction of the Protestant Church of Ireland. He was provost of Trinity College Dublin from 1699 to 1710, and bishop of Cork from 1710 until his death in $1735 .^{1}$

Browne's philosophical career began with his 1697 Letter in Answer to a Book Entitled Christianity Not Mysterious. The book is, as the title suggests, a reply to John Toland's argument against religious mysteries. ${ }^{2}$ One strand of this reply is a defense of analogy as a cognitive tool whereby we are able to have a sort of indirect conception of things of which we, strictly speaking, have no ideas. Browne uses the doctrine of analogy to argue against the Lockean thesis that 'we can have knowledge no farther than we have ideas', ${ }^{3}$ and thereby to undermine Toland's argument for the claim that we cannot believe in religious mysteries like the Trinity.

*Forthcoming in Irish Philosophy in the Age of Berkeley, edited by Kenneth L. Pearce and Takaharu Oda, Royal Institute of Philosophy Supplement Series (Cambridge University Press, 2020).

1. For a detailed intellectual biography, see Arthur Robert Winnett, Peter Browne: Provost, Bishop, Metaphysician (London: SPCK, 1974).

2. John Toland, Christianity not Mysterious: Or, a Treatise Shewing, That There is Nothing in the Gospel Contrary to Reason, Nor Above it: And that no Christian Doctrine Can be Properly Call'd a Mystery, 2nd ed. (London: Sam. Buckley, 1696).

3. John Locke, An Essay Concerning Human Understanding, ed. Peter H. Nidditch (1690; Oxford: Oxford University Press, 1975), §4.3.1. 
Analogy is the central theme that runs through all of Browne's philosophical works, up until his last, and longest, work, Things Divine and Supernatural Conceived by Analogy with Things Natural and Human (1733), usually known (insofar as it is known at all) by the shortened title Divine Analogy. This paper will explore Browne's use of the doctrine of analogy to explain the attribution of knowledge to 'brutes' (i.e., non-human animals), humans, angels, and God. The account to be examined is not a theory of epistemology as ordinarily understood: that is, it is not a theory of epistemic justification or the norms of theoretical rationality. Rather, it is a metaphysical account of what knowledge, as a mental state, really is. ${ }^{4}$ This account, I will argue, bears interesting resemblances to functionalist theories in recent philosophy of mind.

\section{Browne's Theory of Analogy}

David Berman has characterized Browne as a 'right-wing Lockean' of the Irish 'counter-enlightenment,' employing Locke's principles for conservative ends. ${ }^{5}$ Browne himself, however, would certainly not take kindly to being described as a Lockean of any sort. In Divine Analogy, Browne writes,

the University... [has been] unhappily poysoned by an Essay concerning Human Understanding: Which appeared indeed in the Beauties of Style, and Wit, and Language; but all this was the Glittering of the Serpent, to palliate and disguise a long Series of false Principles of Knowledge, directly destructive of revealed Religion especially; and calculated with no small Labour and Artifice for leading youthful and half learned Minds into all that prevailing Ignorance and Infidelity, which sad Experience hath shewn to be the Consequences of them. ${ }^{6}$

Although Browne mostly avoids the use of Medieval philosophical jargon, it would be more accurate to describe Browne as a Thomist than as any kind of Lockean. ${ }^{7}$ However, like many other early readers of Locke, ${ }^{8}$ Browne sees Locke's epistemology as basically Aristotelian in orientation and therefore sees large parts of Locke's theory as compatible with his own Thomistic point of view. In trying to express his Thomistic view in the language of modern philosophy, and trying to defend it against modern opponents, Browne often sounds similar to Locke. This may well be intentional. Whether or not Browne himself saw his project this way, the easiest way for us to approach Browne's theory of

4. In this respect, Browne's theory to some degree resembles 'knowledge first' approaches in contemporary epistemology. See, e.g., Timothy Williamson, Knowledge and its Limits (New York: Oxford University Press, 2000).

5. David Berman, Berkeley and Irish Philosophy, Continuum Studies in British Philosophy (London and New York: Continuum, 2005), 82.

6. Peter Browne, Things Divine and Supernatural Conceived by Analogy with Things Natural and Human (London: William Innys / Richard Manby, 1733), 127-128.

7. As we will see, analogy is the central concept in Browne's philosophy. Browne credits Aquinas ('the Angelic doctor') as the best theorist of analogy to date (Browne, Divine Analogy, 93). However, as we will also see, Browne's own conception of analogy has important differences from Aquinas's.

8. See, e.g., G. W. Leibniz, New Essays on Human Understanding, ed. and trans. Peter Remnant and Jonathan Bennett, Cambridge Texts in the History of Philosophy (1704; Cambridge: Cambridge University Press, 1996), 47-50. 
analogy will be to begin by highlighting four central theses on which Browne is in approximate agreement with Locke, then identify Browne's crucial departure from Locke.

In the first place, then, Locke holds that all ideas are derived from experience. There are two sorts of experience: sensation, which is directed at external objects, and reflection, which is directed at the mind itself. ${ }^{9}$ Here, Browne takes a harder line than Locke, endorsing at full strength the Scholastic maxim that there is nothing in the intellect that was not first in the senses ${ }^{10}$ and holding that 'we have no Ideas but of sensible Objects'. ${ }^{11}$ Browne argues against Locke's ideas of reflection explicitly and at length. ${ }^{12}$ The question of how, according to Browne, we manage to think about the mind and its acts in the absence of ideas of reflection will be addressed in some detail in the next section.

Second, Locke holds that 'Words in their primary or immediate Signification, stand for nothing, but the Ideas in the Mind of him that uses them'. ${ }^{13}$ Similarly, according to Browne, 'Words. . . are external, sensible, instituted Signs of Ideas[,] Conceptions or complex Notions in our Mind; which not being Immediately communicable, cannot be made known to others without some such Indications'. ${ }^{14}$

Third, Locke defines 'truth' as 'the joining or separating of Signs as the Things signified by them, do agree or disagree one with another'. Locke goes on to explain,

The joining or separating of signs here meant is what by another name, we call Proposition. So that Truth properly belongs only to Propositions: whereof there are two sorts, viz. Mental and Verbal; as there are two sorts of Signs commonly made us of, viz. Ideas and Words. ${ }^{15}$

As words signify ideas and inherit their reference from the reference of the corresponding idea, so verbal propositions signify mental propositions and inherit their truth value from the corresponding mental proposition. Similarly, according to Browne, "without some [ideas, notions, or conceptions] affixed to the Words we make use of, we can never form a Mental Proposition answering to the Verbal: Nor can a Word without some of these annexed to it, be one of the Terms in a Syllogism'. ${ }^{16}$

Fourth and finally, since, according to Locke, 'our Knowledge... all consists in Propositions', ${ }^{17}$ and (mental) propositions are constructed out of ideas, it follows that 'We can have Knowledge no farther than we have Ideas'. ${ }^{18}$ Regarding this principle, Browne writes, 'this Assertion may very well be granted to our Freethinkers as true, That we can have no Knowledge without Ideas... and yet

9. Locke, Essay, §§2.1.1-4.

10. Peter Browne, The Procedure, Extent, and Limits of Human Understanding, 2nd ed. (London: William Innys, 1729), 55, 382.

11. Browne, Procedure, 64.

12. Browne, Procedure, 64-69, 102-103, 412-414; Browne, Divine Analogy, 23-29; for further discussion, see Berman, Berkeley and Irish Philosophy, 94-96.

13. Locke, Essay, §3.2.2. In chapter 3.7, Locke carves out an exception for the so-called 'particles' (syncategorematic terms), but this exception will not concern us here.

14. Browne, Divine Analogy, 535.

15. Locke, Essay, §4.5.2.

16. Browne, Divine Analogy, 511.

17. Locke, Essay, §2.33.19.

18. Locke, Essay, §4.3.1. 
be very false in Their Sence of it, which is That we can have no Knowledge of things, whereof we have no ideas'. ${ }^{19}$

This last point is the crucial one. Browne holds that we have only sensory ideas, and sensory ideas are ideas of material things. Thus, if we cannot have knowledge of things of which we have no ideas, we can have no knowledge of any immaterial things, a consequence Browne regards as disastrous. ${ }^{20}$ Browne must therefore hold that we can after all have 'Knowledge of things, whereof we have no ideas.' But having come so far with Locke, how can Browne get off the boat?

The hidden premise needed to get from the claim that there is no knowledge without ideas to the claim that there is no knowledge beyond ideas is what Kenneth Winkler has called 'the content assumption'. ${ }^{21}$ This is the view that the content of any thought is fully determined by the idea the thinker has. In other words, each idea has its own proper object(s), and to have that idea is to have a thought about that object or those objects, and nothing else. Winkler argues that Locke rejects the content assumption. ${ }^{22}$ However, this interpretation has been challenged. ${ }^{23}$ The fact that Locke appears to rely on the content assumption in the argument that there can be no knowledge beyond ideas is an additional piece of evidence that Locke endorses this assumption. Browne's theory of analogy, however, is precisely a strategy for rejecting the content assumption, thereby permitting knowledge beyond ideas while retaining Locke's ban on knowledge without ideas. Analogical thought does require an idea, but the object the thought is about is not the same as the object the idea is of.

Regarding our ability to conceive of immaterial things, Brown writes,

when any thing differs thus totaly in Kind from all things whereof we have any direct Idea or immediate Consciousness; we must either remain utterly Ignorant of its Nature and Properties, without being able either to think or speak of it at all: Or we must form Conceptions of it by substituted Representations, and Analogy with those Beings and Properties whereof we have some direct and immediate Perception or Consciousness. ${ }^{24}$

What is crucial here is the notion of 'substituted Representations.' We have no ideas of immaterial things, and we cannot think without ideas. If, therefore, we are to think of immaterial things, we must do it by 'substituting' some sensible idea in place of the missing idea of that thing. Thus, although we have no 'direct idea' of (e.g.) God, we can use some sensory idea to represent God analogically.

This preserves all four of Browne's points of approximate agreement with Locke: the idea we use to represent God is derived from (sensory) experience; the word 'God' signifies this idea; mental propositions like God is omnipotent are joinings of ideas, and are true if and only if the things signified by the ideas agree; and no such proposition can be formed without a subject idea

19. Browne, Procedure, 409.

20. Browne, Procedure, 402.

21. Kenneth P. Winkler, Berkeley: An Interpretation (Oxford: Clarendon Press, 1989), 39.

22. Winkler, Berkeley, 39-43.

23. Gideon Yaffe, "Locke on Ideas of Substance and the Veil of Perception," Pacific Philosophical Quarterly 85, no. 3 (2004): 255-272; Kenneth L. Pearce, "Locke, Arnauld, and Abstract Ideas," British Journal for the History of Philosophy 27, no. 1 (2019): 75-94.

24. Browne, Divine Analogy, 247. 
and a predicate idea. However, in the case of analogical propositions like God is omnipotent, the ideas are not used to signify their 'direct and immediate' objects, but rather, by analogical substitution, are used to signify some reality of which we have no idea.

Browne says less than one might like about how this substitution actually works, and real clarity about the theory can only be achieved by examination of his particular examples. The central aim of this paper is the examination of one such example, the concept of knowledge. However, before we proceed to the analysis of knowledge, it will be useful to get a slightly better grip on Browne's notion of analogy by seeing how he contrasts it with metaphor.

According to Browne, analogy is a middle path between literal and metaphorical thought and speech. ${ }^{25}$ After Browne's Letter against Toland, William King, the archbishop of Dublin, had also employed analogy to answer objections against Christianity. ${ }^{26}$ However, as the deist Anthony Collins quickly pointed out, King's account did not adequately distinguish analogy from metaphor and therefore arrived at a view on which, strictly speaking, 'God is neither wise nor good' (these attributes being predicated of God only metaphorically). ${ }^{27}$ Similar objections were pressed by the conservative Calvinist John Edwards. ${ }^{28}$ It was partly in response to these critiques that Browne saw the need for a more thorough exposition and defense of the theory of analogy. ${ }^{29}$ Indeed, according to Browne, the response to King is only one manifestation of a larger intellectual trend: Browne claims that all forms of religious dissent (including Socinianism, deism, freethinking, and even atheism) are based fundamentally on the assumption that there is no middle way between literal and metaphorical speech. ${ }^{30}$ The issue of the distinction between metaphor and analogy therefore receives a great deal of emphasis.

According to Browne, both metaphor and analogy involve the substitution

25. Browne, Procedure, 13. As Manuel Fasko pointed out to me, it is interesting that Browne and other philosophers employing analogy in the aftermath of Toland typically characterize analogy as a middle path between the literal and the metaphorical, whereas Aquinas and the other Medieval philosophers from whom the theory is drawn present it instead as a middle path between the univocal and the equivocal (e.g., Thomas Aquinas, The Summa Theologica of St. Thomas Aquinas, 2nd ed., trans. Fathers of the English Dominican Province [London: Burns Oates \& Washbourne, 1920], Iq13a3, Iq13a5). Browne recognizes this fact in his exposition of Aquinas (Browne, Divine Analogy, 94-96) but does not seem to realize that this is different from his own approach.

26. William King, Divine Predestination and Fore-knowledg, consistent with the Freedom of Man's Will (Dublin and London: J. Baker, 1709).

27. [Anthony Collins], A Vindication of the Divine Attributes: In Some Remarks On his Grace the Archbishop of Dublin's Sermon, Intituled, Divine Predestination and Foreknowledge consistent with the Freedom of Man's Will (London: A. Baldwin, 1710), 22. On the exchange between King and Collins, see Kenneth L. Pearce, "Matter, God, and Nonsense: Berkeley's Polemic against the Freethinkers in the Three Dialogues," in Berkeley's Three Dialogues: New Essays, ed. Stefan Storrie (Oxford: Oxford University Press, 2018), §12.1.

28. John Edwards, The Divine Perfections Vindicated: Or, Some Brief Remarks on his Grace William Lord Archbishop of Dublin's Sermon (London: Jonathan Robinson, John Lawrence, and John Wyat, 1710). John Edwards (1637-1716), a Church of England clergyman, should not be confused with another conservative Calvinist, Jonathan Edwards (17031758), an American Congregationalist minister.

29. Browne, Procedure, 11-24. Browne does not usually name living authors, so it is sometimes difficult to identify his targets. The italicized text at Procedure, 18-19 is a series of (near) quotations from Edwards, The Divine Perfections Vindicated. The italicized text at Procedure, 20-22 is a series of (near) quotations from [Collins], A Vindication of the Divine Attributes.

30. Browne, Procedure, 28-32. 
of the idea of one thing to stand for another thing. In the case of metaphor, 'the figurative Words, and Ideas, and Conceptions, are us'd without any Real Similitude or Proportion, or Correspondent Resemblance in the things compared. The Comparison is not founded in the Real Nature of the Things, but is a pure Invention of the Mind and intirely Arbitrary'. ${ }^{31}$ Examples Browne gives here include the use of 'taste', a word originally referring to one of the five senses, to refer to aesthetic judgment, and the description of a stormy sea as 'angry'. According to Browne, in such cases we do indeed substitute not just the word but also the concept for which the word stands, and consider a piece of music as if it were an object of gustatory enjoyment or the heaving waves of the sea as if they were an expression of anger.

A further characteristic of metaphor is that it is not 'absolutely Necessary to a True and Real Knowledge of the Things designed to be expressed or conceived by the substituted Ideas'. ${ }^{32}$ In other words, metaphor is a way of talking and thinking about things of which we have some prior conception: we choose to substitute some other idea in place of the direct and proper idea of the thing in question in order to stimulate the imagination or call attention to certain features of the thing, but metaphorical thought and speech, according to Browne, is never strictly necessary. It can always be translated into literal speech without loss of cognitive content. It is for this reason that, although Browne often speaks of metaphor as involving substitution, he also writes that 'Metaphor is rather an Allusion, than a real Substitution of Ideas': in metaphor, although we make use of 'a very remote and foreign Idea' in thinking about the object, nevertheless some prior non-metaphorical conception of the object is always also present. ${ }^{33}$

Both of these features contrast with analogy. In analogy,

Conceptions and Complex Notions we already have of Things Directly and Immediately known, are made use of and substituted to represent, With some Resemblance, or correspondent Reality and Proportion, Divine things whereof we can have no Direct and Proper Idea, or Immediate Conception or Notion at all. ${ }^{34}$

Browne is here speaking of the particular case of 'divine analogy,' that is, the use of analogy in speaking of God. However, as we will see, he regards analogy as a much broader phenomenon.

Analogy, then, differs from metaphor in that the substitution is not arbitrary but based on a 'Correspondent Reality or Resemblance'. ${ }^{35}$ Further, analogy differs from metaphor in that analogy is a tool whereby we conceive of a 'thing [that] differs. . . totaly in Kind from all things whereof we have any direct Idea or immediate Consciousness'. ${ }^{36}$ We do this by substituting an idea or conception we do have for the corresponding or resembling thing of which we have no idea. It is because of the lack of any direct idea that Browne says that analogy involves a 'real substitution' and not just an 'allusion' as in metaphor. It is also for this

\footnotetext{
31. Browne, Procedure, 106.

32. Browne, Procedure, 106.

33. Browne, Procedure, 142.

34. Browne, Divine Analogy, 107.

35. Browne, Procedure, 141.

36. Browne, Divine Analogy, 247.
} 
reason that Browne says that 'Analogy [is] us'd to Inform the Understanding, as Metaphor and other Figures are, to Affect the Imagination'. ${ }^{37}$

The central puzzle for this kind of account is: what kind of 'Real... Correspondency and Proportion'38 could possibly exist between things that 'differ[]... totaly in Kind' ${ }^{39}$ In the case of religious mysteries, like the Trinity, Browne thinks it is sufficient to say that it is revealed by God that some correspondence or proportion or resemblance exists, although we have no knowledge of this correspondence or proportion or resemblance. ${ }^{40}$ However, in other cases Browne thinks we can say something more contentful about the nature of the correspondence. In what follows I will argue that, in the particular case of knowledge attributions, Browne endorses a kind of proto-functionalism in order to allow for a metaphysically real 'proportion' between things utterly different in kind.

\section{Analogical Knowledge Attributions}

According to Browne, our concept of knowledge and of all other mental states begins from our understanding of ourselves. Browne employs the word 'thinking' to refer to 'the particular way of Knowledge in Man' ${ }^{41}$ Further, according to Browne, 'it... [is] the Essence of a Man to be composed of Soul and Body, and to think by the operation of these two essential Parts in conjunction'. ${ }^{42} \mathrm{We}$ know that thinking involves the body because 'we feel [thinking] to be a Labour of the Brain, and we find our selves as much wearied with intense Thought, as with hard bodily Labour'. ${ }^{43}$ However, according to Browne, we also know that thinking involves spirit.

Regarding our knowledge of spirit, Browne begins by noting that 'the Standard and Oracle of Ideas in our Age' (Locke) holds 'that we have the clearest Idea of active Power from our Idea of Spirit', where 'spirit' is defined as 'a Thinking Substance; which [Locke] labours to shew may be Matter for ought we know'. ${ }^{44}$ In response, Browne insists that this account cannot be correct, since in fact spirits cannot be material, and we have no ideas of immaterial substances. We cannot derive an idea of active power from our idea of spirit, since we have no idea of spirit.

Browne sometimes says that we 'have an immediate Consciousness of the Operations' of the mind, ${ }^{45}$ which might be taken to suggest that he endorses the view of Malebranche and Berkeley that we know our selves and our actions by 'consciousness' or 'reflection' without the mediation of ideas. ${ }^{46}$ In fact,

37. Browne, Divine Analogy, 136.

38. Browne, Procedure, 143.

39. Browne, Divine Analogy, 247.

40. Browne, Procedure, 302-321; Browne, Divine Analogy, 4-8, 118-119.

41. Browne, Procedure, 152. Browne is oddly insistent that this is the 'proper Acceptation' of the word 'thinking', i.e., the correct use of the word according to the rules of English. He provides no evidence in support of this claim. Since, as Browne himself recognizes, the lexicographic issue is not of much philosophical importance, I will treat Browne's usage as stipulative.

42. Browne, Procedure, 80.

43. Browne, Procedure, 150.

44. Browne, Procedure, 73; see Locke, Essay, §4.3.6.

45. Browne, Procedure, 66; cf. Browne, Divine Analogy, 23.

46. Nicolas Malebranche, The Search after Truth, ed. and trans. Thomas M. Lennon and Paul J. Olscamp, Cambridge Texts in the History of Philosophy (1674-1675; Cambridge: Cambridge University Press, 1997), 237-239; George Berkeley, Three Dialogues Between Hylas 
Browne's view is more radical than this. ${ }^{47}$ According to Browne, 'The Mind or spiritual Part of us cannot look upon or into itself, by either a direct or reflex Act... We have no Knowledge of our own Spirit, or of any of its Faculties, but from conscious Experience of its several Ways of Acting upon the Ideas of Sensation'. ${ }^{48}$ Although we have a kind of consciousness of our mental operations, this does not allow us to form ideas of them: 'whenever we Attempt to frame any Ideas, properly speaking, of the Mind's Operations or the Manner of them, they prove no more than Indirect Metaphorical Images borrowed from Sense and Imagination'. ${ }^{49}$ In order to conceive of our mental operations, we must make use of 'Complex Conceptions, formed from a Consciousness of the Operations themselves, and Ideas of Sense taken together' ${ }^{50}$ This consciousness, according to Browne, does not allow the mind to think about its operations 'Abstractedly' because it is no more than the mind's ability to 'observe[] its own Motions and Actions and Manner of operating upon those [sensory] ideas'. ${ }^{51}$ All of our conceptions of mental operations are conceptions of operations performed upon ideas. The ideas form part of the conception and cannot be abstracted away.

Browne's view, then, is that it is by observing the mind's manipulation of sensory ideas that we come to a conception of the mind. In another text, Browne explains,

we observe such Effects with regard to things material and sensible, as we conclude cannot proceed from any inherent Power in themselves; and therefore we rightly infer there must be some other Beings Not material which have the Power of producing such Effects... So that we come to our Knowledge of Power, not from any Direct Knowledge or Idea we have of Spirit; but intirely from our Reasoning upon sensible Objects. ${ }^{52}$

Because of Browne's rejection of ideas of reflection, he applies this account even to self-knowledge: I infer the existence of an immaterial part of myself because I observe myself performing operations that cannot be accounted for by mere matter. ${ }^{53}$

Browne holds, then, that all human mental operations (which are the only mental operations of which we have direct knowledge) involve the cooperation

and Philonous, in Philosophical Writings, ed. Desmond M. Clarke, Cambridge Texts in the History of Philosophy (1713; Cambridge: Cambridge University Press, 2008), 231-234 (cited by marginal numbers).

47. There is considerable interpretive dispute about the views of Malebranche and Berkeley on self-knowledge, so perhaps not all interpreters will agree that the view I attribute to Browne is more radical than the views of Malebranche and Berkeley. However, most interpreters of Berkeley (myself included) hold that we are aware of our mental acts as active. As Ian Tipton puts it, an action 'is not primarily an object for mind but rather something we are aware of through doing it' (I. C. Tipton, Berkeley: The Philosophy of Immaterialism [London: Methuen \& Co Ltd, 1974], 267). See Talia Mae Bettcher, Berkeley's Philosophy of Spirit: Consciousness, Ontology, and the Elusive Subject (London: Continuum, 2007), 69-74; John Russell Roberts, A Metaphysics for the Mob: The Philosophy of George Berkeley (Oxford: Oxford University Press, 2007), 36-39; Kenneth L. Pearce, Language and the Structure of Berkeley's World (Oxford: Oxford University Press, 2017), 126-128. Browne's view of our ignorance of spirit is stronger than this.

48. Browne, Procedure, 108-109.

49. Browne, Divine Analogy, 25.

50. Browne, Divine Analogy, 24.

51. Browne, Procedure, 66.

52. Browne, Procedure, 74.

53. Browne, Procedure, 97-98. 
of a material part and a spiritual part. The material part is, at least to some extent, an object of direct awareness and is a thing of which we can have ideas. The immaterial part is known only by inference, and we have no ideas of it. Recall that Browne accepts the Lockean view that we cannot think without ideas. How then do we manage to think about these hybrid spiritual-material processes? Enter, once again, the theory of analogy.

In the Procedure, Browne describes our acquisition of the concept of spirit as follows:

We have not even the least Direct Idea or Perception of the purely spiritual Part of us; nor do we discern any more of its Real Substance than we do that of an Angel. We are so far from an exact view or intuitive knowledge of it, that we are forced to argue and infer its very Existence from our Observation only of such Operations as we conclude could not proceed from mere Matter; and because we have no direct Idea of it, we express the Nature of it, as we do that of Spirit in general, by the negative Word Immaterial. And as we cannot form one Thought of our Spirit, otherwise than as it is in conjunction with the Body; so neither can we conceive any of its Operations but as performed together with bodily Organs: and therefore it is that we are under a necessity of expressing the Modus of them all in Words borrowed from Sensation and bodily Actions. Thus we say the Mind Discerns, Apprehends, Distinguisheth, or Separates one thing from another; it Draws one thing out of another, which is a Consequence or one thing Following from another. Nay, when we would Attempt to form Ideas of Thinking and all the various Modes of it, they are imagin'd to be so many Motions or Agitations of the Soul, in conjunction with the most refin'd and spiritous Parts of the Body, about the Ideas of sensible Objects. ${ }^{54}$

It is Browne's view that all of our talk about the mind and its operations is analogical: our conceptions of mental operations are constructed from sensory ideas. $^{55}$

Regarding our concept of spirit in general, Browne writes, "the Word Spirit in its first Propriety is used to signify the most volatile and exalted Parts of Matter; and is from thence taken to express an human Soul in Conjunction with Matter; and from thence again transferr'd to represent a purely Immaterial Substance by Analogy'. 56 Thus, quite generally, thought about any kind of disembodied spirit involves a two-fold analogy: first, we substitute ideas of sensible things to stand for human mental operations, all of which proceed by spirit in conjunction with matter. This substitution creates an analogical conception which has the sensory

54. Browne, Procedure, 97-98; cf. Browne, Divine Analogy, 23-28.

55. Browne applies this strategy not only to actions, but also to passions. In fact, Browne would say that the very concepts of action and passion are analogical conceptions arising from the action of one body upon another. In our concepts of passions, we conceive of something happening to the mind, and we conceive of this using the analogy of some bodily motion. Thus, for instance, we speak of falling in love, employing a sensory idea of a bodily fall from some height. (This example is mine, not Browne's.) See Browne, Divine Analogy, 27-28. Browne, however, never addresses the question of how or why we conceive some mental goings on as active and others as passive. I thank Samuel Rickless for raising the question about passions.

56. Browne, Procedure, 118. 
idea as an ingredient. This analogical conception is, by a second iteration of analogy, transferred to stand for the operations of a purely immaterial spirit, creating a second analogical conception that contains the first as an ingredient.

Browne's comments on thinking and knowledge follow this pattern: the concept thinking is constructed from sensory ideas by means of analogy to stand for a certain joint operation of spirit and matter in a human being. The concept knowledge is constructed from the concept thinking by a second analogy in order to form a concept that can apply to purely immaterial beings (angels and God) and also purely material beings ('brutes', i.e., non-human animals). Thus, Browne writes,

we can form no other Notion of Knowledge in an Angel or separate [i.e., disembodied] Spirit except by that of Thinking; but this is no more than an Analogical Conception, which the Mind substitutes instead of the real true manner and kind of Knowledge in Angels which we are utterly ignorant of; and which is as imperfectly represented by Thinking, as their Motion is by the moving of our Feet. ${ }^{57}$

Because, according to Browne, it is essential to thinking (the human form of knowledge) that it be performed by the cooperation of spirit and matter, it is clear that no purely material or purely spiritual being can, properly speaking, think. There is a second reason, according to Browne, why a purely spiritual being could not think: the knowledge of a pure spirit would be 'Intuitive and Instantaneous'. ${ }^{58}$ Thinking, however is successive and not instantaneous. ${ }^{59}$ It is for these reasons that a second analogy is needed.

Browne does admit that we correctly apply knowledge and other mental state concepts to brutes, although they are purely material. However, their form of knowledge, according to Browne, is only that 'which we call by the Name of Instinct; and is realy no other than a Calculation or Disposition of their Senses by the Author of Nature'. ${ }^{60}$ Mental state terms like 'knowledge', Browne says, provide 'the best Analogous Notions and Words we have, to represent those Movements of [brutes] which seem to Mimick the Actions and Faculties of Men'. ${ }^{61}$ These movements are purely mechanical, and it seems that they ought in principle to be comprehensible within a completed physiology.

The case of pure spirits is quite different: 'we know nothing of the true manner of that operation in them, which is answerable to knowledg in us'. ${ }^{62}$

It might be thought that a general concept of knowledge, applicable to purely material and purely spiritual things, could be formed by abstraction. However, Browne denies this. Abstraction, according to Browne, consists only in the removal of part of the content of an idea or conception. However, all of our ideas are sensory, hence all are ideas of material things. Thus, to remove the sensory/material content of an idea or conception would be to remove all of the content. ${ }^{63}$ For this reason,

57. Browne, Procedure, 150; cf. Peter Browne, A Letter in Answer to a Book Entitled Christianity not Mysterious (Dublin: John North, 1697), 42-43.

58. Browne, Procedure, 150.

59. Browne, Procedure, 76, 150.

60. Browne, Procedure, 158.

61. Browne, Procedure, 171.

62. Browne, Letter, 42.

63. Browne, Procedure, 196-199; Browne, Divine Analogy, 106-108. 
If we abstract. . . intirely from our Thinking, which includes the Labour of the Brain; we could form no Notion or Conception of the Wisdom of Spirits in general, much less of the Wisdom of God; and therefore for Want of any such abstract Notion or Idea... we are forced to substitute that of our Thinking, to represent an inconceivable Correspondent Perfection which is in God. ${ }^{64}$

Thus, regarding God in particular, Browne writes,

there is certainly some inconceivable Perfection in God answerable to Human Knowledge; which is obtained by the Labour of Thinking and the Operation of Matter and Spirit in essential Conjunction: Goodness in God is an inconceivable Excellency of his Nature correspondent to what we conceive and express by the same Word in human Nature; And the Similis Ratio or Proportion runs thus, What Knowledge and Goodness are in the Nature of Man, That some inconceivable but correspondent Perfections are in the Nature of God. ${ }^{65}$

The concept of thinking is constructed by the analogical substitution of the ideas of certain bodily motions or operations to stand for certain operations of the human mind, which proceed sequentially and by cooperation of the spiritual and the material, and which are known only by their effects on sensible ideas. The concept of knowledge is constructed by a second analogical substitution, whereby we use the concept of thinking to stand for either purely material or purely spiritual operations that are 'answerable' or 'correspondent' to thinking in humans. Our basic question still remains, however: if these operations are utterly different in kind, what could this 'answerability', 'correspondence', or 'proportion' possibly amount to?

\section{Analogy and Functionalism}

To begin to understand the nature of the correspondence between different forms of knowledge, it will be useful to ask: what basis can we have for attributing knowledge to non-humans? That is, what kind of evidence gives us reason to believe that a non-human has knowledge?

Given the fact that Browne's main focus is our thought and speech about God, and given the importance for Browne of such affirmations as God is omniscient (all-knowing), it is surprising that Browne says so little about this issue. The Procedure does include a chapter with the title 'From the Existence of Things material and human, is inferr'd the necessary Existence of God' (bk. 3 , ch. 8). However, this chapter isn't really aimed at defending the existence of God against the atheist, but rather (as the title suggests) at describing how human beings (rationally) arrive at belief in God. The primary target here is likely Anthony Collins, who had argued that King's analogical theory of the divine attributes undermined all arguments for the existence of God. ${ }^{66}$ Browne therefore gives a one paragraph summary of the argument which he takes his

64. Browne, Procedure, 196-197.

65. Browne, Divine Analogy, 137-138.

66. [Collins], A Vindication of the Divine Attributes. Collins' official position in this tract is a Locke-inspired form of deism. However, there is some question about Collins' sincerity. 
opponents already to endorse and spends the remaining ten pages of the chapter criticizing the Lockean account of how we form the idea of God and defending the view that the argument instead supports an analogical conception of God.

Browne summarizes the basis for our belief in God as follows:

Because the Mind perceives it to be a flat Contradiction that the Beings which have been Produced, taken all together or singly, should produce Themselves; or that they should possibly be produc'd or preserv'd as they are, otherwise than by the infinite Power and Wisdom of an Intelligent Agent: Which first Cause must be Without Beginning; since it is likewise flat Contradiction that he should have made himself. ${ }^{67}$

This is consistent with Browne's general position on the epistemology of spirit, quoted above, that spirits can only be inferred from their effects. ${ }^{68}$

King had pressed a similar line in more detail:

the Descriptions which we frame to our selves of God, or of the Divine Attributes, are not taken from any direct or immediate Perceptions that we have of him or them; but from some Observations we have made of his Works, and from the Consideration of those Qualifications, that we conceive would enable us to perform the like. Thus observing great Order, Conveniency, and Harmony in all the several Parts of the World, and perceiving that every thing is adapted and tends to the Preservation and Advantage of the Whole; we are apt to consider, that we could not contrive and settle things in so excellent a manner without great Wisdom: and thence conclude, that God who has thus concerted and settled Matters, must have Wisdom; and having then ascrib'd to him Wisdom, because we see the effects and result of it in his Works, we proceed and conclude, that he has likewise Foresight and Understanding, because we cannot conceive Wisdom without these, and because if we were to do what we see he has done, we could not expect to perform it, without the exercise of these Faculties.

And it doth truly follow from hence, that God must either have these, or other Faculties and Powers equivalent to them, and adequate to these mighty Effects which proceed from them. And because we do not know what his Faculties are in themselves, we give them the Names of those Powers, that we find would be necessary to us in order to produce such effects, and call them Wisdom, Understanding, and Fore-knowledge... Thus our Reason teaches us to ascribe these Attributes to God, by way of Resemblance and Analogy to such Qualitys or Powers as we find most valuable and perfect

Berkeley alleged that Collins' real intention throughout his officially deistic writings was to insinuate atheism, and David Berman has argued that Berkeley was likely correct about this. See David Berman, A History of Atheism in Britain: From Hobbes to Russell (London: Routledge, 1990), ch. 3. However, some other scholars have been skeptical. See, e.g., Wayne Hudson, The English Deists, The Enlightenment World 7 (London: Pickering \& Chatto, 2009), 101-102; Joseph Waligore, "The Piety of the English Deists: Their Personal Relationship with an Active God," Intellectual History Review 22, no. 2 (2012): 183-184.

67. Browne, Procedure, 447.

68. Browne, Procedure, 74. 
in our selves. ${ }^{69}$

Both Browne and King hold that we attribute power and wisdom to God because these attributes are necessary for the production of the effects God has in fact produced. Our concepts of power and wisdom are derived from the finite power and wisdom of creatures. We know that the power and wisdom of God are utterly different in kind from these, but we apply these concepts because power and wisdom are the attributes that would be needed in order for creatures to produce similar effects. There is no direct comparison between human attributes and divine attributes. Since we do not know what God is like in Godself, no such comparison is possible for us. The comparison is rather between the 'Order, Conveniency, and Harmony' finitely wise and powerful humans may bring about in some limited domain and the 'Order, Conveniency, and Harmony' God has brought about in the universe as a whole. In this way, God is named from God's effects.

King and Browne do not specify their sources for this view, but the analysis differs markedly from that of Aquinas ${ }^{70}$ and bears a striking resemblance to Maimonides. Further, many Christian philosophers in this period, including Browne, had at least some familiarity with Maimonides. ${ }^{71}$ According to Maimonides, the only positive attributes that can be applied to God are those derived from action. ${ }^{72}$ Maimonides explains:

Whenever we apprehend one of God's actions, we apply to God the attribute from which this action proceeds, i.e. call Him by a name derived from that action. For instance, we apprehend the tenderness with which He provides for the formation of the embryos of animals. . Such action on our part would presuppose affection and tender feeling. That is what we mean by mercy, and we therefore use of God the term Merciful... Of course God is not experiencing the feelings of affection or tenderness but such actions as a father will do for his child through pure love, compassion, and affection do emanate from God with regard to His favourites, though they are not caused by affection or change... In the same manner all Divine acts are actions that resemble human actions in springing from certain affections and psychological states, but with God they do not spring from anything that is in any way superadded to His essence. ${ }^{73}$

According to Maimonides, we describe God accurately when we denominate God from God's actions in this way. The words we use are taken from human attributes that produce resembling actions, although these attributes bear no

69. King, Divine Predestination, $\S 4$.

70. Aquinas, Summa Theologiae, Iq13.

71. See, e.g., Pierre Bayle, Historical-Critical Dictionary, Selections, trans. Richard H. Popkin (1696; Indianapolis and Cambridge: Hackett, 1991), 134-139; G. W. Leibniz, Theodicy: Essays on the Goodness of God, the Freedom of Man, and the Origin of Evil, ed. Austin Farrer, trans. E. M. Huggard (1710; La Salle, Ill.: Open Court, 1985), §§262-263; Browne, Divine Analogy, 136-138. Browne's mention of Maimonides is in his summary of the remarks on the divine attributes in William Wollaston, The Religion of Nature Delineated, 5th ed. (London: James and John Knapton, 1731), 101, 114-120. Wollaston frequently quotes Maimonides in Hebrew.

72. Maimonides, The Guide of the Perplexed, Abridged, ed. Julius Guttman, trans. Chaim Rabin (Indianapolis: Hackett, 1995), 71.

73. Maimonides, Guide, 74-75. 
resemblance to anything in God. Maimonides in fact goes farther: he endorses a very strong form of the doctrine of divine simplicity and therefore holds that there is nothing in God corresponding to any of these attributes because there is nothing 'in' God at all: God is God, and there is really nothing more to be said about the divine essence than this.

King seems not to go as far as Maimonides on this last point, since he holds that 'it doth truly follow from hence, that God must either have these, or other Faculties and Powers equivalent to them, and adequate to these mighty Effects which proceed from them'. ${ }^{74}$ Nevertheless, he agrees with Maimonides that the divine attributes are denominated from the resemblances of divine actions to human actions.

Browne's view appears to be similar, since he holds that our observation of the orderliness of the created world is involved, not just in our inference to the actual existence of God, but in the formation of our concept of God. Thus, the divine wisdom is that which produces the orderliness of the universe.

It is here that the comparison with functionalism may be helpful. Functionalism, in contemporary philosophy of mind, is often motivated by consideration of multiple realizability. To use a standard example, at the level of neurology there is little or nothing in common between the states of humans and those of octopus, yet both humans and octopus are capable of pain, hunger, etc. As David Lewis suggested, it even seems conceivable that a Martian with a hydraulic 'nervous system' (and, properly speaking, no nerves at all) could experience pain. ${ }^{75}$ It might be thought that this implies that pain, hunger, and so forth are not physical or neurological states at all, since these states may be had in common by beings that have nothing in common physically or neurologically.

According to the functionalist, this is not so. Instead, mental states can be defined by their causal profile, their 'syndrome of most typical causes and effects'. ${ }^{76}$ Lewis famously drew a comparison to bike locks: the unlocked state is the state in which the lock easily pulls apart, and the locked state is the state in which it doesn't. The internal physical implementation of the lock is no part of the definition of these states, and locks with no physical similarity can be in the same state. Yet these states are nothing over and above the physical. ${ }^{77}$

Although functionalism is typically seen as an effort to preserve some form of physicalism, some philosophers have thought that it is an advantage of functionalism that it allows for the possibility that the mind could be either physical or non-physical. ${ }^{78}$ According to these philosophers, our mental state concepts do not settle this question and so we ought to be able to provide an analysis that is neutral with respect to it. Functionalism accomplishes this.

74. King, Divine Predestination, §4.

75. David Lewis, "Mad Pain and Martian Pain," in Philosophical Papers, vol. 1 (Oxford and New York: Oxford University Press, 1983), 122-130.

76. David K. Lewis, "An Argument for the Identity Theory," Journal of Philosophy 63, no. 2 (1966): 17. Although Lewis initially characterized his view as a version of psychophysical identity theory, it has subsequently been regarded as an early version of functionalism. See Janet Levin, "Functionalism," in The Stanford Encyclopedia of Philosophy, Fall 2018, ed. Edward N. Zalta (Stanford: Metaphysics Research Lab, Stanford University, 2018), §3.4, ht tps://plato.stanford.edu/archives/fall2018/entries/functionalism/. Lewis himself describes his view as 'functionalist' at "Mad Pain and Martian Pain," 124.

77. Lewis, "An Argument for the Identity Theory," 17-18.

78. See, e.g., Hilary Putnam, "Philosophy and Our Mental Life," in Mind, Language, and Reality: Philosophical Papers, Volume 2 (Cambridge: Cambridge University Press, 1975), $292-295$. 
The similarity to Browne should be clear. In the first place, Browne's account is motivated by a kind of multiple realizability problem: knowledge can be attributed to beings whose intrinsic states have nothing in common, including beings who are purely material, beings who are both material and spiritual, and beings who are purely spiritual. Further, the term 'knowledge' for Browne appears to be defined in part by its characteristic effects. There is genuine similarity in the effects produced by knowledge in brutes, humans, angels, and God, although there is no genuine similarity in the intrinsic nature of these forms of knowledge themselves.

My interpretive suggestion is, therefore, as follows. 'Knowledge' for Browne refers to the functional role that, in humans, is played by thinking. This is the role of using information to produce intelligent, goal-directed action.

As Browne frequently emphasizes, thinking is a sequential (temporally extended) process that requires the cooperation of the immaterial spirit with the material brain in order to process the input from the senses and produce the relevant output. This kind of processing does not occur in either brutes or purely spiritual beings. Nevertheless, both brutes and purely spiritual beings engage in intelligent, goal-directed action on the basis of information about the world. Hence something must be playing the knowledge role.

In the case of brutes, this role is played by instinct, which is a purely physical/biological process that could in principle be analysed within an adequate account of animal physiology.

In pure spirits (angels and disembodied post-mortem humans), the knowledge role is played by some immaterial and non-sequential spiritual feature. In our embodied earthly state, we are unable to say anything positive about this feature except that it plays the knowledge role.

In God the knowledge role is played by an infinite, immaterial, non-sequential divine attribute, about which we will never be able to know anything other than that it plays the knowledge role. Nevertheless, we know something in God plays the knowledge role, since we know that creation is an intelligent, goal-directed activity. In this way, Browne develops a kind of proto-functionalist account of knowledge and other mental states that are attributed in common to humans and non-humans, especially God. ${ }^{79}$

There is a theological worry about Browne's view here. As mentioned above, King and Browne seem to depart from Maimonides in allowing that there really is something in God corresponding to these states, contrary to Maimonides' insistence on an extremely robust conception of divine simplicity that would reject any real distinction of states or attributes within God. Historically, in fact, divine simplicity was one of the main motivations for denying that qualities could be predicated univocally of creatures and God: when applied to a human judge, 'justice' and 'mercy' designate two different attributes (which often come into conflict), but as applied to God, both designate God's nature, i.e., Godself. $^{80}$ Hence, these predicates cannot be applied in the same way to God and creatures, and the same is true of all other predicates. As mentioned above, Browne seems to see himself as a kind of Thomist, and Aquinas likewise strongly

79. A functionalist analysis of divine mental states has recently been defended by Kevin Vandergriff, "Naturalism, Theism, and Multiply Realizable Mental States," Religious Studies 54, no. 1 (2018): 91-105.

80. See, e.g., Maimonides, Guide, 68-71. 
insists on divine simplicity, and sees it as a motivation for rejecting univocity. ${ }^{81}$ However, a key component of functionalism (one of its key points of contrast with behaviorism) is that it posits causal interactions between different mental states as part of the causal profile defining those states. Furthermore, Browne constantly insists that analogy requires some real correspondence or proportion, and not a merely imaginary one. As a result, Browne's view appears to be inconsistent with the strong doctrine of divine simplicity, as understood by classical philosophical theologians such as Maimonides and Aquinas. This is an uncomfortable position for a staunch traditionalist who holds up Aquinas as his philosophical hero.

Browne does comment explicitly on the doctrine of divine simplicity at one point in his Divine Analogy, and what he says is surprising. Criticizing some remarks on the doctrine of analogy by John Sergeant, ${ }^{82}$ Browne writes,

He affirms with great positiveness That Mercy, Justice, Power, Wisdom, $E_{c}$. are not all distinguished in the divine Nature. But how doth he know this? Because God is a Simple Being. But how doth he know what Uncompoundedness or Simplicity is in the divine Nature It self? All that he or any Man living can know of it, amounts to no more than a Negation only of all Composition discernible in the Creature: All that can be affirmed of God's Attributes in this Respect is, that there is no Distinction between them which is conceivable, as it is in it self, to the Mind of Man; and that if they are actualy distinct in him, it cannot be after the Same Manner they are distinct in the Soul of Man. But however they are, or are not realy distinct in him; we are under a necessity of conceiving them distinguished after the same Manner we find them in our selves; for otherwise we could neither think nor speak of God at all. God hath made a Distinction between his own Attributes thro' all the Language of Revelation; and I think it becomes Divines to adhere to those Distinctions, and to leave his unintelligible Notion of divine Simplicity to the Metaphysicians. ${ }^{83}$

Browne stops short of actually rejecting the doctrine of simplicity, but his remarks here amount, essentially, to a defense of his practice of completely ignoring that doctrine. If I am correct that Browne sees the real correspondence needed to distinguish analogy from metaphor as (at least in this case) a functional correspondence, and if I am further correct that Browne sees divine simplicity as potentially threatening this correspondence, this would make sense of his discomfort with the simplicity doctrine. Furthermore, it would make sense of why Browne feels the need to criticize that doctrine in his discussion of Sergeant: Browne has just been criticizing Sergeant for failing to distinguish adequately between metaphor and analogy. ${ }^{84}$ For Browne, I suggest, Sergeant's version of the doctrine of divine simplicity is at least partly responsible for that failure.

81. Aquinas, Summa Theologiae, Iq3a6.

82. The long passage quoted (without citation, as usual) at Divine Analogy, 157-158 is from John Sergeant, Transnatural Philosophy, or Metaphysics: Demonstrating the Essences and Operations of all Beings whatever, which gives the Principles to all other Sciences (London: John Sergeant, 1700), 365-368.

83. Browne, Divine Analogy, 160-161.

84. Browne, Divine Analogy, 159. 
Browne is committed, at a minimum, to the claim that we cannot conceive how the kind of real correspondence required for analogy could obtain without a real plurality of divine attributes. Insofar as we are extremely limited in our ability to understand God, this might not precisely rule out the strong classical doctrine of divine simplicity, but it does mean that human thought about God necessarily treats that doctrine as false.

\section{Conclusion}

Analogy is the central theme running through all of Browne's writings. Although this doctrine is, for Browne, primarily of importance for its role in making possible human thought and speech about God, it is a general-purpose cognitive mechanism that is used throughout human thought and speech, including in our thought and speech about human and animal minds. This mechanism works by the substitution of some sensory idea to stand for something that is of a completely different kind from the object of the sensory idea, but nevertheless has a real correspondence to it.

I have argued that, at least in the case of the concept knowledge, this 'correspondence' should be understood as functional. Like functionalists in analytic philosophy of mind, Browne is motivated in large part by multiple realizability concerns: there is a state that we want to attribute in common to things that have no intrinsic similarity. Also like functionalists, Browne solves this problem by emphasizing what the states $d o$, their 'syndrome of most typical causes and effects'. ${ }^{85}$

Despite his rejection of Locke's ideas of reflection, Browne does think that we have more direct insight into the particular nature of human mental states than functionalists typically allow. Further, Browne thinks that this insight shows that the human mind functions by the cooperation of a material substance with an immaterial substance. He is therefore a substance dualist in his conception of the human person - a view contemporary functionalism was specifically designed to avoid. My conclusion, then, is that Browne developed what can aptly be described as a functionalist metaphysics of knowledge and other mental states shared by humans and non-humans. However, he should not be understood as endorsing a functionalist metaphysics of the human mind. ${ }^{86}$

KENNETH L. PEARCE is Ussher Assistant Professor in Berkeley Studies in the Department of Philosophy, Trinity College Dublin. He is the author of Language and the Structure of Berkeley's World (Oxford University Press, 2017) and co-editor (with Tyron Goldschmidt) of Idealism: New Essays in Metaphysics (Oxford University Press, 2017).

85. Lewis, "An Argument for the Identity Theory," 17.

86. Many thanks to all of the participants in the IPAB conference for very helpful and enlightening discussions, and special thanks to Manuel Fasko, Takaharu Oda, and Samuel Rickless for helpful comments on a previous draft of this chapter. 